\title{
Low Grade Lymphoma
}

National Cancer Institute

\section{Source}

National Cancer Institute. Low Grade Lymphoma. NCI Thesaurus. Code C3462.

An antiquated term that refers to a non-Hodgkin lymphoma with low grade histolog ic features. 